Дејан Крстиќ

\title{
СОСТОЈБИТЕ И ПЕРСПЕКТИВИТЕ ВО ПРОУЧУВАҢЕТО И ПРИМЕНАТА НА БАЛКАНСКАТА ТРАДИЦИОНАЛНА КУЛТУРА
}

\begin{abstract}
Апстракт: Во текстот се поместени сопствените ставови и размисли за состојбата и за перспективите во проучувањето и во примената на традиционалната култура на Балканот. Се покажува дека постои голема конфузија поради користење на различни термини и различни сфаќања во научните области, чие поле на работа се однесува на традиционалната култура (фолклористика, етнологија, етнографија, етнолингвистика, антропологија) иако, во основа, станува збор за проучување на еден ист дел од реалноста. Општа тенденција е т.н. антропологизација, односно свртување од проучувањето на традиционалната култура кон проучувањето на современите појави (придобивки од западната цивилизација). Сметам дека проучувањето на традиционалната култура на Балканот е во криза поради намалувањето на општествениот интерес за неа, воопшто. Иако Балканот претставува јазол, место на средба на различни цивилизациски влијанија (западното, медитеранското, ориенталното, источно-европското, а присутни се и остатоци од византиската цивилизација), под влијание на природни околности, повеќевековни етнички и историски процеси, тој претставува подрачје на посебна, балканска, култура или цивилизација, која апсорбирала и голем број културни елементи од спомнатите цивилизации. Кога зборуваме за традиционалната култура на Балканот, мислиме токму на овој културен тип. Не постојат национални традиционални култури (тие се само национален конструкт), туку балканска традиционална култура, која се карактеризира со голема варијантност на архаичност. Во текстот се изнесуваат вредностите на традиционалната балканска култура, кои претставуваат причина за идна научна работа и за нејзината употреба во современиот живот. Во текстот, исто така, од перспектива на моменталната состојба се даваат упатства за одредени идни насоки на работа, во оваа смисла. Во иднина при истражувањето и примената на традиционалната култура треба да се ослободиме од бремето на минатото - немање свест за нејзината вредност, вештачка поделба на нејзиното проучување на неколку помали науки, романтичарско-националистичкиот поглед на неа, досегашните присутни методолошки недостатоци во проучувањето, затвореноста во националнодржавните граници. За реализација на сите овие работи би требало да се реорганизираат научните системи и односот кон употребата на традиционалната култура, а исто така е неопходно да се реализира заедништво на балканско ниво.
\end{abstract}

Клучни зборови: Балкан, традиционална култура, фолклор, етнологија, научно проучување, примена на наследството.

Научниот симпозиум со тема „Фолклор - состојби и перспективи“, одржан во Скопје на 22 и на 23 ноември 2019 година го сфатив како добра можност за преиспитување и изнесување на сопствените ставови и видувања во врска со она со што, како етнолог и антрополог, се занимавам веќе подолга низа години, а тоа е во тесна врска со она што се означува со името фолклор. Дел од размислувањата се поттикнати од излагањата и дискусиите изнесени 
на самиот симпозиум. ${ }^{3}$ Иако темата на симпозиумот нѐ упатува на размислување за сегашноста (состојбата) и на иднината (перспективите), ова преиспитување нужно води кон минатото, упатувајќи нѐ на самиот почеток и на историјата на науките, кои се занимавале и се занимаваат со фолклорот, на согледување на предметот на нивната работа и значењето на нивните фундаментални поими.

Терминот фолклор е создаден од сложенката од англиски јазик folklore, која настанала од зборовите folk со значење 'народ' (во смисла на сиромашни жители на селските средини, чија култура е спротивставена на префинетата култура на градската средина) и зборот lore co значење 'традиција'. Овој термин прв го употребил британскиот археолог Вилијам Џон Томс во 1848 година (Трубарац Матић, 2017, 423-424). Терминот фолклор, значи, според значењето на зборот, изворно се состои од два термини, кои споени упатуваат на севкупната традииија (наследство) на селското (неградско) население. Меѓуутаа, во практиката има голем број потесни или пошироки сфаќањ за значењето на терминот фолклор, така што никогаш не дошло до конечно дефинирање и ограничување на предметот на работа на фолклористиката, науката што се занимава со него. Според едно објаснување, фолклорот го сочинуваат сите форми на материјалната и на нематеријалната култура, кои се создадени како уметнички и културолошки израз на групи луѓе, а под тоа се подразбира и вербалниот фолклор, материјалниот фолклор и обичајниот фолклор (Трубарац Матић, 2017, 423). Значи овде, помалку или повеќе, исто така имаме мошне широко значење на фолклорот - тој речиси го опфаќа целото наследство на одредените групи (недостасува само социјалната култура). Според едно поинакво објаснување, фолклорот е „народното творештво на едно општество или област, сочувано/сочувана со традицијата“. Тој, според тоа објаснување, опфаќа различни форми на народната уметност, посебно на усното творештво, а негова важна компонента е фантазијата. Тој престанал да се развива со појавата на индустријализацијата и исчезнува во модерната епоха. Фолклористиката е посебна научна дисциплина, која го изучува фолклорот, а претставува блиска наука со етнологијата (Markov, 1982). Ако ги игнорираме спомнатите и слични објаснувања на фолклорот, во балканската научна практика терминот фолклор се сфаќа многу потесно - тој помалку или повеќе ја опфаќа само народната традиционална книжевност, етномузикологија и етнокореологија, т.е. усното, музичкото и игроорното наследство, во помала мера и уметничката страна на материјалната култура и духовната обичајна традиција. Како фолклористи, главно се декларираат научници што ги истражуваат овие области, особено оние што се занимаваат со усната традиција.

Во сфаќањето на предметот на работа се забележливи големи преклопувања меѓу етнологијата и фолклористиката. Терминот етнологија е сложенка од грчките зборови ethnos, што значи „народ“ и logos, што значи

${ }^{3}$ Според општото мислење, кое провејуваше за време на симпозиумот, а кое лесно може да се потврди и во стварноста, фолклорот е во криза - и сѐ помалку се смета за релевантна тема за наука и за општеството воопшто. Една од изнесените дилеми се однесува на прашањето: - Дали самиот поим фолклор е застарен? 
„наука“, па според тоа, етнологија е наука за народот. Терминот етнологија е преведен и се користи и на јазиците на одделните народи. Првиот термин наука за народот, и тоа на германски јазик (Volkskunde), го употребил свештеникот, Јохан Готфрид Хердер (кој имал и многу пошироко образование од теолошкото). Освен спомнатиот германски назив, имаме и називи со буквално исто значење во рускиот јазик - народоведение и во полскиот ludoznawstvo. Науката означена со терминот етнологија се поврзува со романтизмот од XIX век и со будењето на нациите. Интересот во тоа време бил насочен кон духот и карактерот на народот, а за народ не се сметала секојдневната група, толпа и маса, туку колектив со духовна и со творечка моќ. Основните идеи на европскиот романтизам ја одредиле етнологијата како наука свртена кон сопствениот народ или кон сопствената нација (Стевановић, $2017,79,80,81)$. Токму поради тоа името на оваа наука често се користи во превод на јазиците на одделните народи - за проучувањето на сопствениот народ да се означи и со сопствен назив. Интересно е тоа дека интересите на Јохан Готфрид Хердер, за проучување на народот, најпрвин резултираат со собирање и со објавување народни песни (1778 година) (Стевановић, 2017, 79), нешто што денес повеќе спаѓа во доменот на фолклористиката, а не - на етнологијата. Зборот етнологија, според тоа, во своето изворно значење, отприлика значи исто што и зборот фолклористика и има исто поле на работа. Меѓутоа, и овој термин, со текот на времето, во различните општествени средини, добил свои специфични значења. Според едно објаснување, етнологијата се занимава со проучување на организацијата на општеството, со човековото материјално и духовно творештво, гледано низ призмата на етносот како човекова заедница, одредена со територијата, историјата и донекаде и со потеклото (Flere, 1982, 171-172). Денес во научните кругови на државите на поранешна Југославија, етнологијата главно се смета за наука што се интересира за: материјалната, социјалната и духовната, главно традиционална култура, но без оние, веќе споменати сегменти, што се сметаат фолклористички (народна книжевност, етномузикологија и етнокореологија).

Во блиска врска со терминот етнологија, па и со терминот фолклористика, е терминот етнографија. Тој е составен од грчките зборови ethnos, што, како што веќе беше речено, значи „народ“ и graphéin, што значи „пишува, опишува“. Тоа буквално би значело опишување на народот (Стевановић, 2017, 80). Овој термин во некои претходни периоди, а некаде и денес, бил синоним на терминот етнологија и подразбирал не само буквално опишување, туку и научно истражување на народот. Под влијание на идеите на романтизмот и на национализмот, тој буквално е преведуван на јазиците на одделните народи, така што имаме и термини пе́prajz кај Унгарците, národopis кај Словаците, narodopisje кај Словенците (Стевановић, 2017, 80), лаографuja $(\lambda \alpha о \gamma \rho \alpha \varphi \dot{\alpha} \alpha)$ кај Грците (споменатите термини кај Унгарците и кај Грците во поширока официјална употреба постојат и денес) (Благојевић, 2005). Во Советскиот Сојуз терминот етнографија останал официјален назив за „наука за народот“ (Стевановић, 2017, 80). Така е, на пример, во времето на постоењето на Советскиот Сојуз, па и денес, и во Бугарија (види: Иванова, $2005,22)$, која била под негово силно влијание. Во државите од поранешна 
Југославија, денес, терминот етнографија се користи за она што го кажува и неговото име - за етнолошките описи, кои подразбираат собирање и систематизирање на материјалот, и се смета за дел и понизок стадиум на етнологијата, кој се однесува само на научно известување, а не и на научно објаснување. Сепак, како реликт од минатите времиња, останале, на пример, имињата на Етнографскиот институт на Српската академија на науките и уметностите и Етнографскиот музеј во Белград, во кои денес ниту еден од вработените не се декларира како етнограф и не се занимава само со опишување на етнолошки појави.

Терминот етнологија е близок со терминот антропологија. Овој термин е составен од грчките зборови anthropos, што значи „човек“ и logos, што значи „наука“, па тоа би значело дека антропологијата е наука за човекот. За разлика од терминот етнологија, кој изникнал од европскиот романтизам и бил насочен кон проучување на сопствените народи, терминот антропологија првпат се јавува кон крајот на XVI век, со потекло од колонијализмот на англосаксонскиот свет и бил насочен кон проучување на колонијализираните, неевропски народи (Стевановић, 2017, 80; Ђорђевић, 2017, 11). Од една страна, како посебна научна дисциплина, постои и физичка антропологија, која се интересира за физичките карактеристики и за развојот на човекот, а од друга страна - културната или социјалната антропологија, која се интересира за културните и за социјалните карактеристики на човекот и која како научна дисциплина се етаблира кон крајот на XIX век, кога се одвојува од другите сродни дисциплини (Ђорђевић, 2017, 11, 12; Lukich, 1982). Терминот културна антропологија се користи во САД, а терминот социјална антропологија во Британија (Milich, 1982a, 310; Milich, 1982b, 603). Значи, терминот културна или социјална антропологија во своето изворно значење претставува синоним на зборот етнологија (па со тоа и на зборовите етнографија и фолклористика), само што има различно потекло од друга научна традиција, создадена во поинакви општествени околности.

По Втората светска војна, со губење на колониите, англосаксонската социокултурна антропологија се свртува кон проучување на сопствените општества. Овие општества, меѓутоа, веќе не се селски, туку индустриски. Поради тоа доаѓ до социологизација на овие науки - кои од социологијата преземаат голем дел во својата работа, т.е. почнуваат да се занимаваат со современи општествени појави и со проблемите на модерните општества. Во таа смисла, полето на работа станува речиси неограничено. Сепак, таа се разликува од социологијата според методологијата - додека социологијата го задржува квантитативниот пристап и анкетата, антропологијата е понаклонета кон квалитативниот пристап, кон длабок разговор и набљудување, кои ги задржува од својата традиција. Исто така, разликата меѓу овие две науки е и во предметот на работа - која се движи на оските несвесно - рационално, креативно - формализирано, спонтано - организирано (при што првото му припаѓа на антропологијата, а второто на социологијата), со тоа што поделбата во оваа смисла не е строга (Ковачевић, 2008, 37-40) иако денес, на глобално ниво, се користат сите термини - етнологија, етнографија, фолклористика, а од крајот на 80-тите години на XX век на глобално ниво се 
востановени термините соичјална/ културна антропологија (Ђорђевић, 2017, 11, 12).

Во државите на континентална Европа, во кои сѐ уште нашироко е присутен терминот етнологија, до скоро под терминот антропологија, без какви било квалификативи, се подразбирала физичката антропологија. Последните децении овој термин, освен во англосаксонскиот свет, и во државите на континентална Европа, без епитет, се користи за означување на социокултурната антропологија. На Балканот, во последната деценија од XX век, антропологијата се свртува кон урбаните општества и современоста, почнувајќи да ја заменува етнологијата, која е свртена кон селските средини и минатото, и покрај тоа што уште од 70-тите години на XX век во Југославија, во етнологијата влегуваа елементи на антрополошката парадигма - таа во тоа време се свртува и кон проблематиката на урбаните средини, па тој период е познат како период на антропологизаџија на етнологијата (Ковачевић, 2005, 15-18; Ковачевић, 2006, 56-61, 75-85; Ковачевић, 2008, 26, 28-29; Kovachevich, 2009; Ђорђевић, 2017, 15; Prica, 2005, 31).

Покрај сето ова, како посебна научна гранка сродна на: етнологијата, фолклористиката и антропологијата, се појавува и етнолингвистиката. Станува збор за гранка на науката за јазикот, лингвистиката, која го истражува јазикот како социјална појава - односот на јазикот и етносот, јазикот и културата, јазикот и митологијата итн. Познати се: руската (московската) семиотичка етнолингвистичка школа, полската (лублинската) когнитивна етнолингвистичка школа и англоамериканската школа на антрополошка лингвистика. Овде станува збор за своевидни структуралистички пристапи. На Балканот големо влијание има руската семиотичка школа. Од една страна, нејзините припадници од Русија интензивно се занимавале и денес се занимаваат со Балканот, а од друга страна, таа имала и свои следбеници на овој простор, во Бугарија, како земја што била под влијание на Советскиот Сојуз уште од времето на социјализмот и во Србија, од крајот на 80-тите години на XX век. Во нејзини рамки, етимолошките и дијалектолошките истражувања се поврзуваат со фолклористичките и со етнографските податоци. Во Србија свои следбеници има и полската когнитивна школа. Во најново време и на Балканот доаѓ до антропологизација на етнолингвистиката под влијание на англоамериканската антрополошка лингвистика (исто така доаѓа до пресврт од традиционалната култура кон современоста) (Ристић, Лазић Коњик, 2018, 346-348).

Поради сето споменато, денес, на Балканот, во врска со именувањето на науките, кои го проучуваат општествениот живот на човекот и на неговата култура и со нивните полиња на работа, имаме голема конфузија. Еве неколку примери: во Македонија, на пример, во Скопје има Институт за фолклор и Институт за етнологија и антропологија, а во Прилеп - Институт за старословенска култура, во чии рамки работат и етнолози. Во Софија, исто така, до скоро, при Бугарската академија на науките, одделно постоеа Етнографски институт со музеј и Институт за фолклор, кои од неодамна се споени во Институт за етнологија и фолклористика со етнографски музеј, каде што сепак постои двојност на тој нов институт и поделеност на етнографите, 
т.е. етнолозите, антрополозите, кои повеќе работат на современоста и на социјалната култура, и фолклористите, кои работат на севкупната духовна традиционална култура (не само со усното и со музичкото творештво) 4 . Етнолингвистите имаат свое место во Секцијата за етнолингвистика при Институтот за бугарски јазик на Бугарската академија на науките. Во Србија, може да се каже дека истражувањето на фолклорот е прилично намалено и е сведено на интересот на поединци (кои во последно време ги обединува обновеното Здружение на фолклористи на Србија). Во Белград постои Етнографски институт во кој речиси сите вработени имаат антрополошки професионален идентитет. Катедрата на Филозофскиот факултет во Белград се нарекува Оддел за етнологија и антропологија, а стручното здружение Етнолошко-антрополошко друштво. Некои од овие два термини се сметаат за синоними, а некои за посебни науки, кои имаат свои посебни области на интересирање и методи. Етнолингвистите работат во Балканолошкиот институт во САНУ во Белград, етномузиколозите - во Музиколошкиот институт на САНУ, додека фолклористиката го има своето место на Филолошкиот факултет, на Катедрата за српска книжевност. Имаме ситуација во која голем број од истражувачите се занимаваат со исти области на истражување и студиите ги завршиле на исти универзитетски катедри, а имаат различни професионални идентитети - некои себе се сметаат за етнолози, некои за етнолози или антрополози, сметајќи ги овие термини за синоними, а некои само за антрополози. Во Загреб има Институт за етнологија и фолклористика, кој се занимава и со она што се смета за домен на класичната етнологија, и со она што се смета за домен на фолклорот, како и со она што се смета за домен на антропологијата.

Сите споменати поими (етнологија, етнографија, фолклор, антропологија, етнолингвистика), според своето значење, се мошне испреплетени. Од изнесените податоци, меѓутоа, гледаме дека сите тие -, а тоа го покажуваат и нивните буквални значења -, изворно значеле исто, односно, проучување на човекот како општествено битие, т.е. на материјалните, духовните и социјалните манифестации на неговата култура и на неговата социјализација и општество, и тоа во најширока смисла. Станува збор, за една наука, која има повеќе називи и која има единствено, веке споменато поле на работа, кое е поврзано со еден ист дел на животната реалност на човекот. Можеби во целиот научен свет нема поголема конфузија во смисла на сфаќањето и именувањето на едно исто поле на работа.

Јасно е дека оваа конфузија на поими и нивните значења се создале поради повеќе промени во научните традиции и парадигми во текот на последните два века, предизвикани од промената на општествените услови на

\footnotetext{
${ }^{4}$ Според познатиот бугарски етнолог Радост Иванова, во Бугарија, со основањето на Институтот за фолклор на Бугарската академија на науките во 1974 година, е извршена институционална поделба на една наука на етнографија и фолклористика, што е резултат на организираната борба на одредени личности на административните места, која трае до денес и која се претвора во вештачка бариера меѓу научниците (Иванова, 2005, 22).
} 
светско, на регионално и на национално ниво. Инаку, идејата за научно проучување на манифестациите на човековата средина, потекнуваат од западната цивилизација, а исто така и повеќето научни парадигми што влијаеле врз прифаќњето на различните поими и на нивните различни значења: голем број тешкотии, кои се однесуваат на сегашната состојба и на состојбата во иднина на споменатите дисциплини, можат да се надминат со подигање на свеста за тоа дека тие само наизлле се посебни науки, но всушност тоа е една различноименувана наука, чие дејствување е бесмислено, и која реално може да има само специјализации за одредени области, како и отфрлање на неприродни стеснувања и омеѓување на полиьата на работа поврзани за одделни поими.

Се создадоа голем број на сомнежи врзани за дефинирањето на предметот на работа што пак беше под влијание и на смената на културата на голем дел од населението во втората половина на XX век. До половината на XX век доминираше т.н. народна, селска, традиционална култура (во неа не припаѓаа малобројните балкански елити, кои ги прифатија културните модели на соседните доминантни културни кругови - ориентален или западен). Од идејата на европскиот романтизам и национализам, од кои произлезе и општиот интерес за овие науки, нужно следи дека предметот на работа треба да биде токму народната култура, културата што е карактеристична за најголемиот дел од народот. Меѓутоа, од втората половина на XX век, со процесите на интензивна индустријализација, урбанизација и модернизација, а и во екот на глобализацијата, западната култура на Балканот ја потисна традиционалната култура. Иако има остатоци на традиционалната култура и денес, науките што се занимаваат со неа - етнологија (или етнографија) и фолклористика - се соочуваат со исчезнувањето на предметот на работа, што меѓу етнолозите и фолклористите предизвикува недоумици и колебања. Во Србија, на пример, од 70-тите години на XX век, некои етнолози започнуваат да ги прифаќаат методите на англосаксонската културна или социјална антропологија, пред сѐ, на структуралната и на семиотичката и да се интересираат и за современи теми (што до 90-тите години на XX век се нарекувало урбана етнологија), а од 90-тите години се именува како социологизирана антропологија која се интересира за современите појави (Ковачевић, 2005, 15-18; Ковачевић, 2006, 56-61; Ковачевић, 2008, 26, 28-29; Kovachevich, 2009). Овие тенденции се карактеристика и на други балкански национални науки за народот. Во Србија оваа крупна промена на научна парадигма, покрај тоа што денес имаме мошне малку етнолози што работат на традиционалната култура, подразбира дури и екстремни и омаловажувачки мислења дека етнологијата пред нејзината замена со антропологијата била квазинаучна, со образложение дека била инструмент на романтизмот и на национализмот и дека била недоволно теориски поткована (Ковачевић, 2005, 11-15; Ковачевић, 2006, 47-55, 84, 85, 90, 108, 109; Ковачевић, 2008, 26; Kovachevich, 2009, 9, 11, 28, 29). Додека балканските етнологии, со пренасочување од традиционалното кон современото, т.е. со антропологизирање, се трансформирале и на тој начин го тргнале проблемот на недостатоците кои се однесуваат на предметот на својата работа, 
балканскиот фолклор, без разлика што во негови рамки имало и сѐ уште има обиди за работа на неговите понови видови, сепак останал цврсто поврзан за традиционалните истражувања, што во голем дел е причина за неговата криза денес, поради исчезнувањето на традиционалната култура. Според ова, на Балканот настапува, помалку или повеке, криза во проучувањето на традиционалната култура или на традиционалното наследство (која порано главно е нарекувана народна култура, но овој термин е депласиран со фактот дека повеќето народи на овие простори не се веќе нејзини носители).

Мошне е позитивно тоа што науката, за социјалните и за културните страни на човекот, со современата антропологизација се ослободува од ограничувањето да се занимава само со културни форми од минатото и да ја занемари сегашноста само затоа што современата култура не припаѓа на културен тип, кој порано бил препознаен како значаен. Тоа е пред сѐ позитивно во епистемиолошка смисла, од аголот на најопштата потреба за спознанието и науката. Меѓутоа, современата антрополошка парадигма, во практиката на балканското подрачје е релативно брзо прифатена што, помалку или повеќе, носи друг вид исклучивост - ориентираност кон современите појави, а игнорирање и, дури понекогаш, потценување на проучувањето на традиционалната култура. Во оваа смисла се појавуваат и крајно екстремни мислења. Исто така, доминацијата на западната цивилизација на Балканот се гледа не само во научната сфера, туку и кај општествената елита воопшто. Традиционалната култура, како рурална и спротивна на елитната, има немарен или често и потценувачки однос, па така на Балканот опаѓа не само научниот, туку и воопшто општествениот интерес за традиционалната култура.

Ваквата ситуација го наметнува прашањето и за потребата втемелена врз научното промислување на општествениот однос кон традиционалното наследство денес и во иднината. Која е смислата на неговото проучување? Дали тоа, во иднина, како предмет на работа, може и треба да има свое место во балканските науки за културата и социјализацијата на човекот, како и да се нарекувале (фолклористика, етнологија, етнографија, етнолингвистика, антропологија)? Дали сознанијата за него во иднината можат да имаат своја функција во балканските општества?

Потреба од темелни преиспитувања на односите кон традиционалната култура нѐ упатува нас, пред сѐ, на прашањето што е традиционална (порано народна) култура на Балканот.

Балканскиот Полуостров е цивилизациски јазол - тука се среќаваат и се вкрстуваат културни елементи на: западноевропската, медитеранската, ориенталната и источноевропската цивилизација. На Балканот има елементи од сите овие цивилизациски кругови. Многу луѓе Балканот го сфаќаат и како подрачје на премин меѓу Западот и Истокот. Тој, меѓутоа, не е само место на средба на овие културни елементи. На него има и живи остатоци на византиската цивилизација, а според тоа, благодарејќ́ на ситуацијата на специфичните природни услови (планинскиот релјеф), интензивните и сложените етнички мешања (Балканот со милениуми е јазол на миграции од североисток, северозапад, исток... ) и особените историски и други околности 
(на пример, расцепканост и слабост на православните цркви, специфичности на уредување на Османлиското Царство... ), тука постои и еден автентичен, оригинален, културен слој, кој, без разлика на силните културни влијанија отстрана, го задржува својот континуитет од неолитските времиња ${ }^{5}$ до денес (иако денес пред нашите очи забрзано исчезнува под влијание на западната цивилизација). Тоа е балканскиот културен слој, чија основа е неолитската култура, која, со исчезнувањето на некогашните урбани форми на живот градовите, настанала селската култура, спротивставена на урбаната култура, култура на малите селски аграрно-сточарски заедници, на природното стопанство наспроти трговско-занаетчиско-административно-воените градски заедници во кои се менувале елитните култури на различните цивилизации (Stojanovich, 1995, 23-29; Stojanovich, 1997, 34-41). Тој балкански слој е обликуван така што културните елементи на различните етнички групи и владејачките цивилизации, кои доаѓале отстрана, се калемеле еден на друг, со што се појавиле нови квалитети - со прифаќањето на балканската култура, тие добиле посебна балканска црта и се балканизирале. Станува збор за оној културен тип кој во чиста форма долго се чува во некои пасивни планински предели на Балканот, кај планинците („горштаците“), во планинскиот релјеф, скриени од влијанијата на странски цивилизации, тип што антропогеографот и балканологот Јован Цвијиќ го нарекувал патријархален режим (Цвијић, 1991, 122-126). Можеби ова именување е неадекватно, но е важно дека Цвијиќ го согледал постоењето и посебноста на овој културен слој во однос на културните влијанија на споменатите цивилизации. Тој ги прикажал зоните на цивилизациските влијанија на Балканот и картографски го прикажал просторот на кој доминира овој тип култура (Цвијић, 1991, карта 120 и 121). Врз основа на постоењето на овој етнокултурен слој, земајќи ги предвид и сите културни влијанија од страна, балканологот Трајан Стојановиќ зборува дури и за балканска циивилизаџија (Stojanovich, 1995; Stojanovich, 1997). Темелејќи го своето мислење врз сопственото етнолошко-антрополошко искуство и врз познавањето на балканското етнокултурно наследство, и самиот сум склон да го користам терминот балканска циивилизација, кој покажува дека балканскиот човек припаѓа на еден оригинален цивилизациски круг, кој не е ниту западен, ниту ориентален, а не е ниту медитерански, ниту источноевропски. Голем број луѓе мислат дека овој термин е прејак, но, во секој случај може да се користи терминот балканска култура, кој го задоволува значењето на овој иако, мошне разновиден, а сепак доста сеопфатен културен комплекс.

Токму балканската култура, помалку или повеќе, контаминирана со различни културни елементи на другите цивилизации, е она што ние, на Балканот, го нарекуваме традиционална култура или традиционално наследство 6 . Балканската култура, како што беше кажано погоре, подолго и во

5 Во традиционалната култура на Балканот наоѓаме, несомнено, низа неолитски културни форми.

${ }^{6}$ Традиционално е во однос на западната култура, која од половината на XX век, со процесите на: индустријализација, модернизација и урбанизација, станува доминантна на Балканот. 
почиста форма се одржувала во пасивните планински предели. Колку повеќе подрачјето е планинско, толку оваа култура била повеќе сочувана, а колку било пониско или со поразвиени комуникации (крајбрежје, рамнини и речни долини), влијанијата отстрана оставале подлабоки траги. Елементите на културите донесени отстрана секогаш, па и денес, се сметале за поавангардни и во поголема мера се прифаќани во урбаните, градските средини, додека во попасивните селски средини, балканската култура се одржувала со многу помалку контаминираност од странски влијанија. Меѓутоа, и таму каде што влијанијата отстрана се подоминантни, мошне се присутни изворни балкански културни форми, а тие често, како што е веќе нагласено, добиле нов квалитет, и се преоблекле во балканско руво.

Во врска со балканската култура е важно и тоа дека нејзините елементи не се застапени само на Балканот. Како што околните цивилизации влијаеле врз културата на Балканот, така и балканската култура влијаела врз нив. Додека елементите на околните цивилизации доаѓале со прифаќањето од страна на балканските општествени елити како престижни, елементите на балканската култура главно се ширеле на други начини - со преселба на балканското население на подрачјата на другите цивилизации. Балканот, како главно пасивно планинско подрачје, во долг временски период бил биолошки „резервоар“ на едно население, кое, заради подобри услови на живот, мигрирало, а и денес мигрира во подрачјата на другите цивилизации. Иако на подрачјата на населување ги прифаќало придобивките на тие цивилизации, во нив внесувало и елементи на својата балканска култура. Затоа можеме да кажеме дека Балканот, во културна смисла, е многу поширок од своето географско подрачје. Во најголемиот дел од Романија, на пример, балканските културни елементи се многу доминантни. Важен расадник на балканските културни елементи се Карпатите, во кои долго се задржала балканската култура во почиста форма. Поради тоа некои балкански културни елементи наоѓаме дури и во: Словачка, Украина и Молдавија. Голем дел од балканските културни елементи има и во јужниот дел на Панонската Низина, која била населена од балканско население со векови. Елементите на балканската култура стасале и во земјите на Западна Европа: Словенија, Австрија, Германија, Швајцарија, Франција и др., а исто така и во Северна Америка и Австралија. Таму тие се чуваат во рамките на балканските мигрантски заедници, како дел од нивниот етнички идентитет.

Западноевропската и медитеранската цивилизација ги карактеризира голема контрола од световните и духовните елити (нивните власти), врз секојдневниот живот, во текот на долг историски период (во духовна смисла тоа е силнодолгорочна активност на католичката и на протестантската црква), интензивна долготрајна стопанска комуникација, т.е. интензивен проток на стока и на идеи, со кои се мешаат и се изедначуваат културните форми поттикнати од забрзаната модернизација и од брзиот технолошки развој. Истокот, исто така, има големо, силно, долготрајно влијание на световните и на духовните власти врз секојдневниот живот (во духовна смисла тоа е решително влијание на исламската религија) и интензивна размена на стоките и идеите преку трговската комуникација, со што, исто така, културата на 
пошироките слоеви на населението на широкиот простор се изедначува. Спротивно од тоа, Балканот мошне долго бил на перифериите на влијанието на овие цивилизации и неговата култура во голем број негови делови долго се развивала без голема контрола на власта и без големо влијание на официјалните религии, надвор од значајните трговски патишта и, така да се каже, сѐ до половината на XX век, не вршела позначајно влијание врз процесите на модернизацијата на секојдневниот начин на живот на пошироките слоеви на населението. Благодарејќи и на овие факти, балканската традиционална култура има некои особини, кои ја немаат споменатите цивилизации. Додека нив ги карактеризира голема униформност на културата, балканската култура, спротивно на ова, ја карактеризира голема разновидност на културните форми - мултиплицирање на истите културни идеи на различни микропланови на многу различни начини. Додека спомнатите цивилизации ги карактеризира доминација на владејачките идеолошки и религиски обрасци, балканската култура ја карактеризира чување на архаичните културни форми (како што веќе кажавме, дури и неолитски), кои преживеале различни идеологии и официјални религии и кои, во големата етнографска целина, биле присутни до половината на XX век, а ги наоѓаме и денес. Додека спомнатите цивилизации ги карактеризира владеење на официјалните религии во мошне чисти, канонски форми, на Балканот, религискиот живот го карактеризира религискиот синкретизам - во рамките на официјалните религии во „свежа“ форма живеат и старите религиски форми, од времето пред прифаќањето на тие религии. Тоа е посебно карактеристично за зоните, кои, на Балканот, се населени од православно население од словенското и од романското говорно подрачје.

Мошне е важно да се нагласи дека на Балканот не постои ниту еден традиционален културен факт на кој би можеле да му припишеме строго национален карактер - тие се локални, или со потесен или со поширок регионален, па дури и со општобалкански карактер, при што нивното распространување никогаш не е поврзано со националните граници. Познато е дека на просторот на распространување на секој балкански народ и на територијата на секоја балканска држава, постојат по неколку различни, но по многу нешто и мошне сродни, јасно воочливи, етнографски зони, односно поттипови на традиционалната култура, од кои многу се протегаат и на просторите на соседните народи и држави. Фактички, посебни национални традиционални култури на Балканот не постојат - како посебни тие се само научни и општествени конструкти, кои се плод на романтичарсконационалистички идеи и кои немаат основа во стварноста. Значи, традиционалното наследство на Балканот не треба да се дели на: национални, религиски или некои други традиционални култури, туку да се гледа како единствен етнокултурен систем ${ }^{7}$. Секако, во врска со посебноста на

7 Уште во 1903 година, српскиот етнолог Тихомир Ѓорѓевиќ еден свој текст го почнува со следниве зборови:

Одамна веке е забележано дека во народното предание, особено во епската поезија, кај балканските народи постои мошне голема сродност, која понекогаш доаѓa дури до идентитетот. [Тука во фуснота упатува на текст на еден германски 
балканската култура секогаш треба да се има предвид дека таа во својата изворна форма, во најдлабоките слоеви, има некаква врска, заеднички корен, па со тоа и мноштво културни паралели со сите индоевропски и блискоисточни култури.

Дали ваквата балканска традиционална култура има вредност, која би требало да биде причина за сегашната и идната насоченост и научно и воопшт, за општествената насоченост кон неа? Според моето мислење, таа има голема и неминлива научна и општествена вредност, а причината за намалениот интерес за неа, е резултат на општата криза и на кризата на општествената свест на Балканот. Оваа свое тврдење го темелам врз следните факти:

1. Традиционалната балканска култура има епистемолошко, когнитивно значење. Балканското традиционално наследство, како цел еден специфичен културен комплекс, пребогат со содржина, важно е да се проучува, пред сѐ, заради едноставната и фундаменталната потреба за знаење. Зошто да се откажеме од кое било, па и од ова цело едно поле на истражување и разбирање на појавите во тоа поле? Ниту во Западниот свет, од кој доаѓаат современите антрополошки научни парадигми на Балканот и воопшто размислувањето, кое, на неговите жители, им носи отстапување од сопствената традиционална култура, не се откажале од научното проучување

автор од 1902 година, во кој тој изнесува некои заеднички елементи на народната поезија на балканските народи].

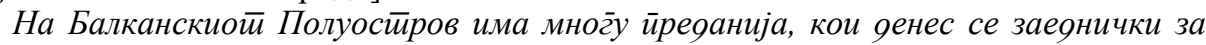

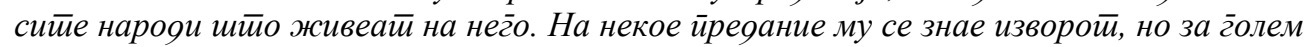
број не знаеме ирвобийно кому му йрийаг̆ал, кој нароя навистиина г̄и йозајмил на

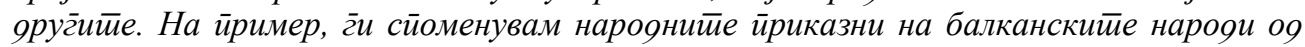

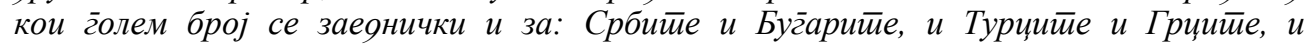

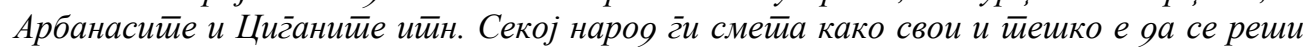

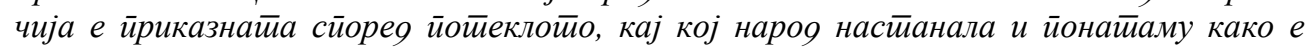

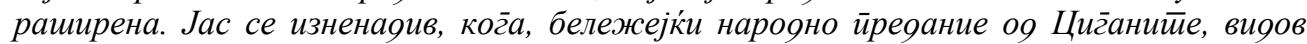

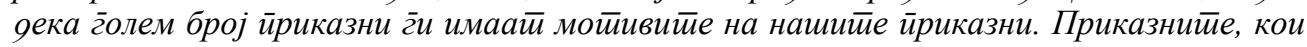

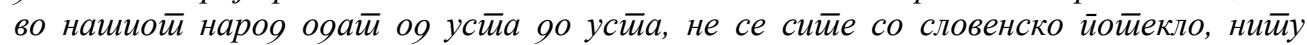
ирвобийна наша сойсиивености, иикку голем яел оя нив се йозајмени. На некои се знае

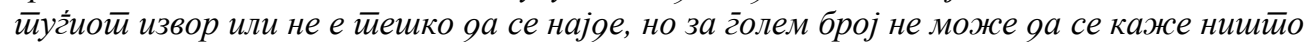
со сигуурносй.

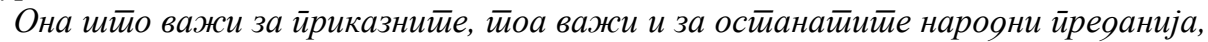

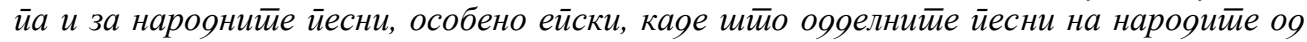

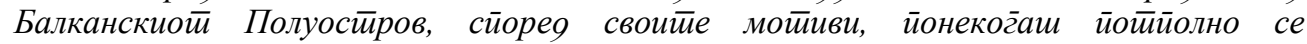
иоклойуваай, истио како и некои ирриказни.

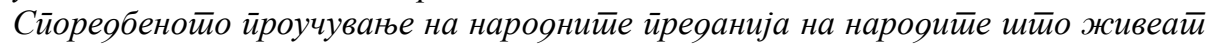

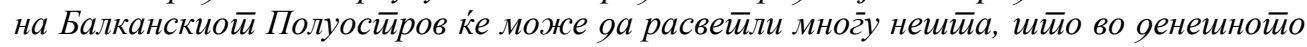
йреgание е нејасно и нейознайо (Ђорђевић, 1903, 179).

По овој увод Тихомир Горѓевиќ укажува на тоа дека варијантите на една позната српска епска песна од збирката на Вук Караџиќ е забележена и во Дебар и во Кукуш, во Македонија, како и дека една варијанта е забележана и кај Циганите, на цигански јазик, а во овој текст тој изнесува и нотен запис и превод на една варијанта забележена кај Албанците (Ђорђевић, 1903, 180-184). 
на традиционалните култури и од архаичните културни форми од минатото. Напротив, ваквите култури и културни форми се во постојан фокус на нивното научно внимание. Исто така е и во научните системи на Исток. На пример, традиционалната култура на Балканот, пред сѐ на балканските Словени, и во овој миг е актуелна тема на руските етнолингвисти (чие седиште се наоѓa во Институтот за славистика при Руската академија на науки во Москва). Кај голем број народи од средна и од источна Европа, исто така, е прифатена современата антрополошка парадигма, но сепак останал интересот за традиционалната култура.

2. Традиционалното наследство на Балканот има особено културолошко значене. Тоа значење од една страна се темели врз: оригиналноста, исклучителното богатство, т.е. исклучителната разновидност, како и исклучителната архаичност на содржината на балканската култура, а од друга страна, таа, како таква, е оригинален $и$ значаен дел на општото наследство на човештвото. На Балканот се сочувани оригинални и често мошне архаични форми на културата, кои имаат врски и со многу рани и значајни фази на европската и на светската култура. Станува збор за културна област која се наоѓa на просторот на „првата Европа“, од каде што потекнуваат и го започнале својот развој голем број општочовечки достигнувања и придобивки (неолитизација, античка култура, христијанство...). Додека околните цивилизации постојано оделе кон новото, Балканците сочувале многу нешто од старото. Затоа немаме право, од која било причина (поради моменталните научни парадигми, поради комплексот на недоволни вредности, поради прифаќањето на туѓи општествени и културни матрици...) научно и, воопшто, општествено да ги занемариме оригиналните културни факти на еден цел културен комплекс, кој го чуваме и кој ги содржи споменатите карактеристики што му даваат дополнителна вредност.

3. Традиционалната балканска култура, во сите свои варијанти, едноставно е наша, таа е нашето културно наследство, ние сме нејзини наследници и поради тоа би требало кон неа, макар и само по таа основа, да имаме позитивен однос и да работиме на нејзиното проучување, познавање и афирмирање. Сите напредни општества се занимаваат со своето културно наследство, какво и да е тоа, па можеме да кажеме дека позитивноста и сериозноста на односите кон сопственото наследство е показател на развиеноста и успешноста на одредено општество. Кој треба да се занимава со нашето традиционално наследство ако не самите ние? Тоа, за припадниците на балканските средини, меѓу другото има и идентитетско значење. Токму неговите елементи, во различните варијанти, се маркери (симболи) на локалните и на националните идентитети. Традиционалното наследство е она оригинално и единствено на Балканот, тоа е она што го прави балканското подрачје посебно.

4. Сознанијата за балканската култура се неопходни за антрополошко проучување на современите појави во балканските средини. Иако западната култура денес е доминантна на Балканот, далеку од тоа дека таа е застапена во чиста форма. Таа апсорбирала и голем број елементи од балканската култура 
заедно со сите балканизирани елементи на околните цивилизациски кругови, кои, на Балканот, се прифатени во раните периоди. Всушност, можеме да кажеме дека современата култура на Балканот претставува синкретизам на западната култура и на балканската традиционална култура. Затоа и современото антрополошко проучување на Балканот речиси е невозможно без добро познавање на неговото традиционално наследство. Современата антрополошка парадигма ја носи, покрај другото, и појавата со Балканот да се занимаваат антрополози што не ја познаваат балканската традиционална култура (најмногу и поради тоа што учењето за традиционалната култура е драстично намалено, а понекогаш и речиси протерано, од универзитетските катедри), а доколку се има предвид дека тие често, во потполност, се и носители на животниот урбан стил на западната цивилизација, тогаш тоа укажува на тоа дека тие немаат доволно животно искуство со неа. Тоа често доведува до тоа, кога современите појави имаат и балкански културни елементи, тие да не можат да го разберат докрај својот предмет на работа. Често антрополозите со современа ориентација, кои не ја познаваат балканската култура, кога ќе навлезат подлабоко на балкански терен, надвор од големите урбани центри, потполно се дезориентирани и мошне тешко се снаоѓаат. Значи, без сознанието за балканската култура, во голем дел се одрекуваме од квалитетните сознанија за современите процеси на Балканот воопшто.

5. Сознанијата за традиционалната балканска култура се корисни и за проучување и за разбирање на културата на соседните подрачја на околните цุивилизации. Не само што тие околни цивилизации, како што е веќе кажано, влијаеле врз културата на балканските народи, туку како што видовме и погоре, балканската култура влијаела врз нив. Познавањето на балканската култура е потребно, од една страна, за проучување на елементите во традиционалните култури на соседните цивилизации, кои останале од поранешните, претопените, балкански мигранти, а од друга страна за проучување на одредени антрополошки појави, т.е. на современи општествени појави, кои се последица на современото масовно мигрирање на Балканците во средини што им припаѓаат на тие цивилизации.

6. Традиционалната балканска култура е применлива во современиот живот на населението на Балканот. Таа може да биде употребена за негова благосостојба. На пример, традиционалната балканска култура може да биде применлива во туризмот, на неа може да се темели цела една гранка на културниот туризам, и тоа од неколку причини:

1. Оваа култура е поврзана со руралните средини, т.е. со природните амбиенти, кои веќе се потенцијали за природен и рекреативен туризам;

2. Во однос на западната култура, таа е поинаква, друга, а и архаична, па поради тоа припадниците на западната цивилизација ја доживуваат како егзотична;

3. Многу нејзини придобивки, на пример, музика, гастрономија итн., можат да придонесат за потенцирање на чувството за уживање и задоволство. Поради тоа, таа претставува важен туристички потенщијал. 
Иако на Балканот постои одредена туристичка етнопонуда, нејзините капацитети не се доволно искористени (види: Крстић, 2018; Крстић, 2014; Крстић, 2017, 175-201). Освен туристичко значење, кое засега е во рамките на економијата (бидејќ туризмот е стопанска гранка), од исти причини традиционалната култура на Балканскиот Полуостров е применлива и во позитивната презентација на Балканот и на балканските општества воопшто (од последната деценија на XX век до денес, подрачјето на Балканот е обременето со голем број негативни стереотипи). Промоцијата во туризмот е работа на подигање на свеста за вредноста на балканската култура, како кај оние кои ја презентираат, така и кај оние на кои таа им е презентирана. Таа, исто така, може да биде применлива и во други области на современиот живот на Балканот и пошироко - во: екологијата, педагогијата, забавата, психотерапијата, регионалната политика...

Значи, факт е дека ни се потребни сознанијата поврзани со традиционалната култура на Балканот. Сега, кога таа, под ударот на западната цивилизација, односно на процесот на: модернизација, урбанизација и глобализација (кои се вршат според западниот модел), исчезнува пред нашите очи, треба да сумираме и да размислиме што треба да правиме во овој миг (каква е состојбата?), а што во иднина (какви се перспективите?). Повеќе од двесте години на Балканот се истражува традиционалната култура, но, во врска со нејзиното проучување и користењето на нејзините потенцијали, работата ниту оддалеку не е завршена. Токму тука лежи одговорот на прашањето дали и какви перспективи имаат балканските науки кои се занимаваат со традиционалната култура, како и да се нарекуваат тие; во оваа смисла нив ги очекува голема работа.

Кога станува збор за научното проучување, важно е, без оптоварување од научните традиции, да се согледа состојбата и на идната работа во оваа област во врска со двата основни сегменти - научно известување и научно објаснување. Кога станува збор за научно известување, може да се каже дека навистина, по околу два века работа на традиционалната култура на Балканот, имаме мошне голем емпириски материјал, огромна етнографска граѓ, која е огромен и значаен извор на научното известување за неа.

Во текот на размислувањето за таа етнографска граѓа, мораме да бидеме свесни дека гледано од аголот на денешните методолошки барања, научните известувања имаат свои недостатоци. Голем дел од материјалите ги собрале луѓе без стручно и методолошко образование, дилетанти (априори - без негативна конотација на овој израз). Во периодот од крајот на XIX и на почетокот на XX век, на Балканот немало формално етнолошко образование, па сѐ што е собрано во тој период, фактички е производ на дилетантско дејствување. И подоцна, сѐ до денес, овој вид луѓе активно собираат етнографска граѓa. Нив, меѓутоа, во позитивна смисла, отсекогаш ги карактеризирало она што ги карактеризира и сите формално образовани луѓе во овие области - особената заинтересираност за предметот на работа, 
која често била извор на голем ентузијазам и причина за импозантни истражувачки потфати, до таа мера што придонесот на некои поединци може да се мери со придонесот на цели институции. Недоволноста од потребното знаење, пред сѐ, од областа на епистемологијата и методологијата на научното истражување, негативно се одразило врз собраниот материјал. Во голем број случаи е нарушено методолошкото начело на прецизност - многу податоци не се прецизно временски, просторно и/или содржајно одредени. Кога станува збор за временските одредби, често се немало свест за динамичноста на податоците, за нивниот временски контекст; тие се сметани за безвременски и скаменети остатоци на минатото. Во врска со просторните одредувања, често не се давани податоци за точната локација на нивното потекло и за информаторите од кои се добиени; општа постапка била да се даваат само информации за тоа на кои пошироки етнографско-географски области им припаѓаат. Со тоа се создава впечаток дека описите важат буквално за цели области, што не одговарало на реалноста бидејќи, поради исклучителната веќеспомената варијантност на балканските традиционални култури, во стварноста податоците се разликуваат не само од село до село, туку и од поединец до поединец. Кога станува збор за содржинските одредби, често се јавуваат површни, недоволно прецизни или недоволно исцрпни описи. Исто така присутна била и појавата на „дотерување“ и селекција на податоците, инспирирана од национално-романтичарски, естетски и/или морални побуди.

Оптовареноста со романтичарските и националните идеи е мошне присутна, ако се има предвид дека и самата идеја за работа на ова поле потекнува од истите идејни системи. Таа понекогаш била изразита, па и доминирала над научното и спознајното. Токму оваа појава е еден од поводите за спомнатите екстремни критики, со кои целата традиционална етнологија се прогласува за квазинаучна (Ковачевић, 2006, 83-84, 108, 110; Kovachevich, 2009, 6).

Меѓутоа, сметам дека овие критики се преостри. Прво, собирањето на некои етнографски материјали, колку и да е инспирирано од романтизмот и од националните побуди и колку и да имаат методолошки недостатоци, тие, во одреден помал или поголем степен, имаат спознајна вредност и се употребливи во науката. Второ, без разлика на романтичарско-националните побуди, кај најголем број собирачи, чувствата за документарност и вистинитост биле подоминантни и тие не се нарушени. Трето, особено во поново време, во втората половина на XX век, не сите собирачи биле мотивирани од романтизмот и од национализмот. Нив често ги водело научно оправданото чувство дека треба, додека уште постојат, да се забележат податоците и да се создадат изворите за една култура која исчезнува. Поради овој трет факт, всушност, карактеристиката на класичната етнологија во подоцнежна фаза се должи на недостаток од теоретски пристапи и занимавањето со етнографија за етнографски цели е бесцелно собирање на податоци за традиционалната култура (Ковачевић, 2006, 104-105, 109, 111; 
Ковачевић, 2008, 30; Kovachevich 2009, 11) ${ }^{8}$. Ке го наведам својот пример: поголемиот дел од животот, до денес, континуирано и со голем жар се занимавам и со етнографска работа и точно знам поради што го правам тоа не од романтичарско-националистички причини, бидејќи не сум ниту романтичар, ниту националист, ниту поради некој бесцелен манир, туку заради чувството на совест, спознанието и длабокото убедување дека традиционалната култура има своја голема научна и воопшто општествена вредност и значење, дека научното известување, изворите, за неа како предмет на научна работа, треба да се зголеми (индуктивното заклучување е повистинито доколку има повеќе елементи врз чија основа може да се донесе заклучок), дека нејзините елементи и придобивки трајно исчезнуваат и дека ако не бидат забележани, како информации, тие засекогаш ќе бидат изгубени. Станува збор за она исто чувство, кое ја содржи и целта според која се води, на пример, еден археолог за време на ископување на остатоците на древните цивилизации; a, како што знаеме, кредибилитетот и значењето на археологијата, како наука во денешните научни и воопшто општествени дискурси, не е под знак прашање.

Значи, досега е собран огромен фундус на граѓ за традиционалната култура на Балканот (етнографска, фолклористичка). Како извор на научно известување за неа, има свои недостатоци, за кои мораме да бидеме свесни и секогаш да ги имаме предвид, но, без обкир на тоа, тој неоспорно, севкупно гледано, има исклучителна спознајна вредност и значење. Станува збор за море од етнографска граѓa која е доволна за добивање увид во целината на балканската култура.

Во врска со етнографската граѓa за традиционалната култура на Балканот, во иднина треба да се работи на следните работи кои треба да бидат дел од јасна стратегија, да се вршат смислено, интензивно и организирано, со полна свест за нивната цел и значење, и кои треба да бидат институционално и воопшто општествено поттикнувани и поддржувани:

1. Собирање на граѓата. Балканските национални науки за народот се зафаќаат со пошироки систематски собирања на граѓата што повремено се реализира. ${ }^{9}$ Никогаш не биле ниту близу до систематски организирано исцрпно истражување на целата своја територија. Поради тоа, за жал, неизмерно многу граѓa за балканската традиционална култура, со непроценлива вредност, неповратно исчезнала, а процесот на интензивното исчезнување трае веќе повеќе децении и пред нашите очи се одвива неговата завршна фаза. Има критичари на традиционалната етнологија, кои велат и дека е собрано доволно граѓа за традиционалната култура и дека етнографските истражувања веќе немаат смисла (Ковачевић, 2006, 113). Овие критики, според мое мислење, не „држат“, ако се има предвид исклучителната, веќе спомената, варијантност и разновидност на балканската

\footnotetext{
8 Антропологот Иван Ковачевиќ, кој ги изнесува овие критики, во еден миг ја квалифицира како селско-ливадска етнографија (Kovachevich, 2009, 6).

${ }^{9}$ Еден од најголемите организирани потфати во оваа смисла е антропогеографскиот проект на Јован Цвијиќ.
} 
традиционална култура и на фактот дека често некои, дури и наизглед безначајни детали и варијанти, можат да бидат важни, а понекогаш и клучни за време на научните анализи на нејзините појави. Затоа, дел од: перспективата, иднината, науката или науките што се занимаваат со неа е интензивно собирање на етнографската граѓ за традииионалната култура додека сѐ уште ја има на терен. Треба да се спасат податоците што сѐ уште можат да се спасат. Во таа смисла, треба да се работи и на подобрување на квалитетот на чување на етнографските предмети во музеите и во различните етнографски збирки. Етнографската работа (главно со методите на длабински разговор и разгледување со учество или без учество, а и собирање и чување на етнографските предмети) има длабоко епистемолошко (спознајно) оправдување - со него се создаваат и се збогатуваат изворите на научниот извештај. А колку повеќе има извори, толку се поголеми можностите за научно заклучување.

2. Приредување и објавување на собраната, а досега необјавена граѓ. Голем дел од етнографската граѓa за балканската култура, односно изворот на научното известување за неа, е собран, но сѐ уште не е публикуван и е складиран во личните архиви на: истражувачите, архивите на институциите ${ }^{10}$ и депоата на етнографските музеи и збирки. Тоа се информации кои се спасени од заборав и потенцијално ги имаме, но поради нивната мошне ограничена и намалена достапност за науката во овој миг, речиси како и да ги немаме. Поради тоа, една од големите задачи во перспектива на балканските науки е приредувањето и објавувањето на собраната, а досега необјавена етнографска граѓa. Необјавената граѓa, во најмала рака, може да се дигитализира и да се направи достапна за пошироката јавност дури и без приредување и објавување во писмена форма;

3. Зголемување на достапноста на веќе објавената граѓa. Голем дел од граѓата е објавена во публикациите, кои, поради минувањето на времето, поради малиот тираж или поради својот локален карактер на истражувачите, не се лесно достапни. Поради тоа треба повторно систематски да се објавуваат. Тоа може да се прави со публикување на репринт или нови изданија, по можност со текстови за нив, како и нивно дигитализирање $и$ објавување во дигитална форма или ставање на увид на интернет. Оваа потреба ја потврдува и фактот што во делата за традиционалната култура на Балканот, главно се цитира еден потесен круг од позната литература, онаа објавена во издание на научните установи, а потполно е занемарено морето од податоци објавени надвор од оваа литература, во изданијата со локален карактер и во неспецијализираните и други списанија.

4. Систематизирање и воопштување на граѓата. Голем проблем во врска со огромниот комплекс на граѓa за традиционалната култура на Балканот е тоа што таа е несистематизирана, расфрлана по различни списанија, зборници и монографски публикации, па во овој миг е невозможно да се создаде претстава за нејзината целина. Во историјата на проучувањето на балканската култура, се разбира, има примери на систематизирање на

${ }^{10}$ Некои балкански институции чуваат непубликувана етнографска граѓа дури од XIX век. 
материјалот: колку што ми е познато, има само еден посериозен пример на генерализирање на податоците од целиот Балкан; тоа е книгата Балканско полуострво/ Балкански полуостров од Јован Цвијиќ (со извесни, во некои делови и сериозни, недостатоци, пред сѐ поради националистичката пристрасност), каде што има повеќе примери на тематско систематизирање на материјалите на национални рамништа во поранешна Југославија, дури и примери за систематизирање на целиот нејзин простор, што значи дека книгата истражува повеќе нации, а во изданијата на руските етнолингвисти, примерите се поврзани со балканските Словени. Меѓутоа, сите овие систематизации се во многу мал број споредено со големината на материјалот за балканската традиционална култура. Затоа, една од големите неопходни задачи на науките кои се занимаваат со традиционалната култура претставува идната активна работа на систематизација преку објавување на материјалот и тоа на различни начини, на пример, со: приредување и издавање на тематски зборници со материјали (со критички воведи на приредувачите), изработка и публикување на тематските сумарни текстови, библиографии, класификации, прегледи и индекси со граѓa. Во текот на изработката на библиографијата секако треба да се вклучи и библиотекар.

Освен споменатите работи поврзани со полето на научното известување, претстои голема работа во врска со традиционалното наследство на Балканот и е дел од перспективата на балканските науки кои се занимаваат со него, а поврзани со научното објаснување. Во досегашната историја на балканските науки, „за народот“ има доста единечни примери на научно толкување и објаснување, понекогаш и мошне сериозни. Овие објаснувања се резултат на примената на компаративниот метод и методите на различните теориски насоки: функционализмот, дифузионизмот, структурализмот, етнолингвистичката семиотика, современите теории на етницитет и други. Имало, меѓутоа, и објаснувања, кои, од современ агол на гледање се депласирани научно, а кои се правени од позиција на: еволуционистичката, марксистичката и другите теории, или, пак, од позиција на романтичарсконационалистичките и други идеолошки погледи на светот, а посебно била раширена теориската неизграденост на формално образованите, па често се среќаваат и наивните шаблонизирани објаснувања, кои се, исто така, еден од поводите за критика на традиционалната етнологија (Ковачевић, 2005, 11-15; Ковачевић, 2006, 47-55, 103-104, 108, 109; Ковачевић, 2008, 26; Kovachevich, $2009,11,28,29)$. Сѐ на cѐ, во однос на квантитетот на материјалот за балканската традиционална култура, како и за нејзиниот квалитет, т.е. богатство и комплексност, сразмерно, мошне малку дела содржат квалитетни научни толкувања и објаснувања; во проучувањето на традиционалната култура претежно се останало на ниво на опис, на научен извештај. Затоа, дел од стратегијата за иднината треба да биде и институционално и воопшто општествено поттикнување и помагање на работата на поединците кои се во можност да се фатат во костец со научните објаснувања поврзани со балканската традиционална култура, секако од аспект на своите теориски погледи, и да даваат толкувања, размислувања и критики засновани на научни принципи. Исто така, треба, во што поголем број, да се организираат 
конференции посветени на одделните прашања поврзани со оваа култура, врз чија основа ќе се иницираат објаснувањата и толкувањата и до кои ќе се доаѓа со размена на мислења. Интензивното и континуирано одржување на научните конференции е една од карактеристиките на развиените научни системи. Во овој миг, на Балканот има мошне мал број конференции посветени на традиционалната култура.

За разлика од природните науки, каде што се подразбира дека целта е употребливоста и применливоста на научните сознанија, во голем број општествени науки на Балканот, па и во оние кои се занимаваат со традиционалната култура, применливоста во практиката речиси и да ја нема. ${ }^{11}$ Доаѓа, така да се каже, до своевидно фетишизирање и задоволство од научното објаснување, т.е. во раната фаза на науката оние што се занимаваат со традиционална култура сметаат дека е доволен описот содржан во научното известување, односно фактичкото познавање на некоја појава. Во Србија, на пример, во рамките на современата антрополошка парадигма, постојат екстремни мислења дека етнолозите треба да се занимаваат исклучиво со наука и тоа со современи теми, односно антропологија, во денешна смисла на зборот, и дека треба да се дистанцираат од „занаетчиската“, т.е. музејска работа и од други видови на применета етнологија (Ковачевић, 2008, 26, 33-34). Неучеството во креирање на современиот живот е една од причините поради кои се намалува општествениот интерес за науките што се занимаваат со традиционалната култура, воопшто.

Можеби единствениот пример за професионална и донекаде научно втемелена примена на знаењето за традиционалната култура (со многу недостатоци во овој поглед) е нејзиното претставување во музеите и ретките етнопаркови, за културни, идентитетски и економски (туристички) цели. Во иста насока е и дејствувањето на националните професионални фолклорни ансамбли (танцување - пеење - свирење), од културни и идентитетски причини. Традиционалната култура доста се користи во фолклорниот (играчко-пејачко-свиречки) аматеризам, во угостителството (етнокафани) и воопшто во гастрономијата, но главно мошне дилетантски, без употреба на научни сознанија и без учество на стручните лица. Поради тоа, тука мошне е застапена појавата на фолклоризмот - со користење на елементи кои само личат на традиционални, а всушност не се. Општо е мислењето дека на Балканскиот Полуостров со употребата на традицијата може да се занимава секој и дека стручните лица за тој вид активност не се потребни.

Поради сето споменато, задачите на науките за народот во иднина се и: развивање на свеста кај научниците кои се занимаваат со нив, а и во општеството воопшто, за традиционалната култура како потенцијал што може да се стави во функција на современиот живот, кој може да биде користен за доброто на современиот човек; прифаќањето на применетоста на науките кои се занимаваат со традиционалната култура како еден од деловите на научното и на стручното дејствување, односно работа врз развивањето на применетата

11 Иако, на пример, на Одделот за етнологија и антропологија на Филозофскиот факултет во Белград постои предмет Применета антропологија. 
етнологија и фолклористика; промислување на разните можности и начини за употреба на традиционалното наследство врз основа на научните сознанија и со учество на стручните лица; што пошироко реализирање на видовите на примена на сознанијата за традиционалната култура. Некои од конкретните задачи се, на пример: осмислено и планско ширење на мрежата на етнографски музејски поставки и етнопаркови, правење на презентации во музејските установи и етнопаркови, зголемување на бројот на манифестации со етносодржини, воведување на традиционални елементи во различните области на животот (педагогија, екологија, уредување на ентериерот и екстериерот, мода, забава, гастрономија, промоција на сопствените микро и макрозаедници, подобрување на меѓуетничките и меѓурелигиските односи врз основа на близината во традиционалната култура и врз основа на традиционалните модели на соживот... ), воспоставување на стручна и научна контрола врз дилетантската употреба на традицијата. Со зголемување на учеството на традицијата во современиот живот и со создавањето на тој живот, ќе се зголеми и општиот општествен интерес за науките и потребата од нив, а ќе се подобри и статусот на оние што се занимаваат со нив. За да се постигне ова, клучна би била застапеноста на традиционалната култура во наставата во училиштата во многу поголема мера: освен на етнолошките факултетски катедри, каде што треба да се отворат и посебни оддели за нејзино изучување и образование на стручните кадри, таа треба да биде застапена, на пример, и како задолжителен средношколски предмет во склоп на предметите како што се: историја, социологија, филозофија, уметност...

За успешно спроведување на научните објаснувања и за примената на научните сознанија за традиционалното наследство на Балканот, потребно е да се направат одредени радикални чекори во смисла на поинакви начини на размислување во науките кои се занимаваат со традиционалната култура и со нивната нова научна организација.

Прво, треба да се работи на подигнување на свеста за вредноста на традиционалната култура, како кај пошироките слоеви на населението, така и во стручните кругови кај кои евидентно се намалува интересот за традиционалната култура. Традиционалната култура треба да се маркира како валидна и значајна научна и општествена тема. Покрај тоа, треба да се потенцира дека токму ние, Балканците, треба да се занимаваме со својата традиционална култура, бидејќи ние најдобро ја познаваме и ја чувствуваме, ја впиваме помалку или повеќе со својата социјализација. Во таа смисла треба, пред сѐ, да се надминат наметнатите комплекси и негативните стереотипи за сопствената култура од Запад. Токму под влијание на западната култура, која во овој миг е елитна, се губи интерес за сопственото традиционално наследство, не само кај пошироката популација, туку и во етнолошките кругови кои сега стануваат антрополошки и се свртуваат кон проучување на западните влијанија во своето општество, занемарувајќи, а понекогаш, како што видовме, и омаловажувајќи ја традиционалната култура. Создаден е комплекс на пониска вредност на сопствената култура поради која и самите Балканци сакаат да се оддалечат од неа и да се осврнат на туѓa култура, без да ги согледаат нејзините многубројни вредности. Не е добро во науката за 
културата и во општеството да се држи само до традицијата и до минатото. Се разбира, постои потребата и за проучување на современоста, но тоа не треба да значи прекинување со темите кои се однесуваат на традиционалната култура. Една од причините е и когнитивна - на човекот му е својствено да се интересира и за своето минато, па затоа, на пример, никогаш не е поставено прашањето за смислата на постоењето во низа на историски науки. Може да се каже дека кај современите антрополози дошло до своевидно фетишизирање на сегашноста, што, според моето мислење, нема смисла, меѓу другото и поради тоа што сегашноста веќе утре станува минато, но и поради тоа што и нивните теми, ако се има предвид динамичноста на културата, по релативно кратко време престануваат да бидат актуелни. Вистината е на средина - треба еднакво да се посветува внимание и на традиционалното и на современото.

Понатаму, треба да се надминат институционалните поделби во науката која се занимава со традиционалната култура, олицетворена во различните називи какви што се: етнологија, етнографија, фолклористика, етнолингвистика, антропологија. Треба да се инсистира на единство на науката - сите дејности што традиционално се поврзуваат со било кој од овие термини треба, на државно ниво, да бидат под исти институционални капи. Формално (немам увид во суштинското функционирање) добар пример е оној од Хрватска, каде што во Институтот за етнологија и фолклористика во Загреб, се занимаваат и со класична етнологија, со класична фолклористика и со антропологија. Значи, не треба да се ограничува предметот на работа, ниту содржински, ниту просторно, туку спротивно на тоа, да се шири, и тоа со прифаќање на новите теми и научни парадигми со рамноправно задржување на старите. Разликите рефлектирани во различните термини би можеле само да се одразат врз поделбата на одделенија и сектори и да бидат предмет на личните афинитети и специјализации на секој поединец.

Без оглед на современите тенденции на зголемено прифаќање на терминот антропологија, сметам дека терминот етнологија е најсоодветен за Балканот, како обединувачки поим за сите науки што се занимаваат со традиционалната, а и со современата култура, вклучувајќи ја и културната антропологија: терминот на задоволувачки начин го покрива предметот на работа; тој упатува на тоа дека станува збор за наука (-логија); неговата содржина ја опфаќа и содржината на терминот етнографија; тој е попрецизен од терминот антропологија бидејќи директно упатува на групата, општеството и културата на човекот, за разлика од терминот антропологија кој упатува на човек во најширока смисла на зборот, вклучувајќи го и неговото природно битие, па со квалификациските префикси културна или социјална е потребно да се прецизира на кој предмет на работа се однесува; терминот е дел од повеќето балкански научни традиции, а и воопшто од европски; потекнува од Балканот, од грчкиот јазик (за разлика од терминот фолклор, кој потекнува од англискиот јазик). Но, од друга страна, не пречи и сите термини да бидат во функција ако, тие, не се сфатат во строго тесна смисла, ако се сфатат како своевидни синоними. Јас, на пример, себе, без какви било проблеми можам да се наречам: и етнолог, и етнограф, и антрополог, и фолклорист, не само поради тоа што моите интереси и активности се упатени на потесните 
области, кои ги означуваат сите овие термини, туку и поради тоа што сите овие термини ги сметам за еден вид синоними, со кои се означуваат појавите од областа на едно-исто поле на работа.

Во идното истражување на традиционалната култура на Балканот многу е важно да се ослободиме од големото бреме од минатото: од романтичарските и од националистичките мотиви при собирање материјал и при нивната обработка и толкување, како и од погореспоменатите методолошки недостатоци - непрецизни временски, просторни и содржински определувања на материјалот, паушални и површни објаснувања. Поради надминување на овие проблеми потребно е да се изгради свест за фундаменталните карактеристики на традиционалната култура на Балканот за нејзината ненационална природа, и за нејзината динамичност и исклучителна варијантност, а и да се применат сите стандарди на модерната научна логика и методологија.

Ако се има предвид дека науките на Балканот се организирани на државно-национално ниво, а станува збор за една, балканска, култура, треба да се работи на надминување на затвореноста на размислувањето и на дејствувањето во рамките на државно-националните граници и на обезбедување на соработка и единство во проучувањето на ова наследство на целиот Балкан. На ова размислување му соодветствува и тоа што со стремежите на балканските средини кон европските интеграции се зголемила и нивната меѓудржавна и меѓународна соработка, вклучувајќи ја и научната. Кога станува збор за Балканот, порано соработката била поинтензивна меѓу институциите на ниво на Југославија како државна заедница. Во поново време институциите од Бугарија во голема мера ја зголемија соработката со институциите во: Македонија, Србија и Хрватска. Поради блискоста на јазиците, комуникацијата меѓу земјите на словенските јазици се поинтензивни. Меѓутоа, пред сѐ, поради јазичните бариери, контактите со институциите на земјите со несловенски јазици какви што се: Романија, Грција и Албанија, се многу помали кога станува збор за балканската традиционална култура во интеракција со институциите од другите балкански земји, односно како да се позатворени во своите државно-национални рамки. На пример, поради јазичните ограничувања, а и чувството за национална самостојност, во нив помалку се компарираат материјали од териториите на другите балкански држави, како што и нивните материјали во другите балкански држави помалку се земаат предвид. Во иднина, со цел поврзување, соработка и заедничко дејствување на балканските науки кои се занимаваат со традиционална култура, треба да се работи на надминувањето на овие појави. Еден од начините е и преведување на етнографската и на фолклористичката граѓa, а вториот е организирано учење на јазиците на соседните народи и запознавање со нивната граѓa, литературата и достигнувањата во областа на проучувањето, како и на презентирањето на традиционалната култура. Во секој случај, задачата за во иднина треба да биде интензивна работа на поврзување и соработка, остварување на некој вид заедништво, меѓу балканските научни институции кои се занимаваат со работа на ова поле. Во таа смисла, голем чекор би била заедничката координирана работа, па и 
заедничките проекти за одделните традиционални појави од Балканот, во кои би учествувале претставниците на сите или барем на поголемиот број држави. Мошне корисно за спроведување на таквата работа би било основање на Балканска асоцијација на структурите кои се занимаваат со традиционалната култура. Како обединувачки и координирачки фактор, би можел да биде и заеднички Балкански комитет за проучување на традиционалната култура на Балканот или друго тело со поинакво име, а кое би имало претставници од сите држави и народи на Балканот. Во идната работа е важно и што потесно поврзување и заедничка работа со центрите на проучување на традиционалната балканска култура надвор од Балканот, со каква било теориска ориентација (како што е тоа, на пример, Институтот за славистика во Москва). Исто така е значајно и поврзувањето со поединците надвор од неговата територија, кои имаат афинитет кон проучувањето на неговата традиционална култура.

Покрај заедништвото во проучувањето на традиционалната балканска култура, во иднина би требало да биде застапено и заедништвото во нејзината примена во современиот живот. Би требало, на пример, заеднички да се работи на промоција на Балканот, заеднички да се изгради неговиот единствен имиџ со давање и промовирање на потполно нови димензии на неговата традиционална култура, особено со оглед на тоа дека станува збор за посебна, мошне богата и разновидна култура или цивилизација, која сочувала голем број архаични форми кои имаат корени во најдлабоките културни слоеви на човештвото. Токму врз овие факти треба да се гради и туристички имиџ на Балканот и неговата туристичка понуда. Врз основа на овој имиџ и поглед на Балканот, освен остварување на економската корист, преку туризмот, разбивање на негативните стереотипи и постигнување поголем углед на сите држави на меѓународен план, може да се оствари уште многу поголема и позначајна корист: градење на свеста за заедничката традиционална култура што, со текот на времето, би резултирало со многу поголема блискост меѓу балканските народи, без која на сцена го имаме Балканот како „буре барут“, што денес, за жал, многу луѓе ја гледаат како негова основна карактеристика.

\section{ЛИТЕРАТУРА}

\section{Кирилични изданија}

БЛАГОЈЕВИЋ, Г. (2005). „О лаографији и антропологији у Грчкој“. Етнологија и антропологија: Стање и перспективе. Зборник Етнографског института САНУ, бр. 21. Гавриловић, Љ. (ур.) Београд: Етнографски институт Српске академије наука и уметности, 55-65.

ЂОРЂЕВИЋ, И. (2017). „Антропологија“. Етнологија и антропологија: 70 изабраних појмова. Гавриловић, љ. (ур.) Београд: Службени гласник, Етнографски институт Српске академије наука и уметности, 11-16.

ЂОРЂЕВИЋ, Т. (1903). „Бола Хјусен-ага: Једна арбанашка варијанта српске народне песме“. Карацић, лист за српски народни живот, обичаје и предање, бр. 3, год. IV. Алексинац, 170-184. 
ИВАНОВА, Р. (2005). „Бугарска етнологија - стање и перспективе“. Етнологија и антропологија: Стање и перспективе. Зборник Етнографског института САНУ, бр. 21. Гавриловић, Љ. (ур.) Београд: Етнографски институт Српске академије наука и уметности, 21-27.

КРСТИЋ, Д. (2014). „Култна места као потенцијал руралних средина“. Бити соииолог села: Споменица Ђуре Стевановића. Ђорђевић, Д. Б. (ур.). Нови Сад, Ниш, Београд: Прометеј, Машински факултет, Балканска асоцијација за социологију села и пољопривреде, 269-290.

КРСТИЋ, Д. (2017). Тимочко село: стање, проблеми, потениијали. Нови Сад, Ниш, Зајечар: Прометеј, Машински факултет, Народни музеј.

КРСТИЋ, Д. (2018). „Етнокултурни потенцијали балканског села“. Замтита животне средине, обнова и развој сеоских подручја. XXIV Међународна научна конференција „Власински сусрети 2018“ [во печат].

КОВАЧЕВИЋ, И. (2005). „Из етнологије у антропологију (Српска етнологија у последње три деценије 1975 - 2005)“. Етнологија $u$ антропологија: Cтање и перспективе. Зборник Етнографског института САНУ, бр. 21. Гавриловић, Љ. (ур.) Београд: Етнографски институт Српске академије наука и уметности. 11-19.

КОВАЧЕВИТ, И. (2006). Традииија модерног: прилози историји савремене антропологије. Београд: Српски генеалошки центар, Одељење за етнологију и антропологију Филозофског факултета.

КОВАЧЕВИЋ, И. (2008). „Српска антропологија у првој деценији двадесет првог века“. Гласник Етнографског музеја у Београду, књ. 72. Београд: Етнографски музеј, 25-40.

РИСТИЋ, С., ЛАЗИЋ КОЮИК, И. (2018). „Развојне тенденције етнолингвистике у савременој српској лингвистици“. Српска славистика: Колективна монографија: Радови српске делегачије на XVI међународном конгресу слависта. Том I: Језик. Драгићевић, Р. и В. Брборић (ур.). Београд: Савез славистичких друштава Србије, 345-356.

СТЕВАНОВИЋ, Л. (2017). „Етнологија“. Етнологија и антропологија: 70 изабраних појмова. Гавриловић, Љ. (ур.) Београд: Службени гласник, Етнографски институт Српске академије наука и уметности, 79-81.

ТРУБАРАЦ МАТИЋ, Ђ. (2017). „Фолклор“. Етнологија $u$ антропологија: 70 изабраних појмова. Гавриловић, Љ. (ур.) Београд: Службени гласник, Етнографски институт Српске академије наука и уметности, 423-429.

ЦВИЈИЋ, J: (1991). Балканско полуострво. Београд: Српска академија наука и уметности, Завод за уџбенике и наставна средства, Новинскоиздавачка радна организација „Књижевне новине“.

\section{Латинични изданија}

FLERE, S. (1982). „Etnologija“. Socioloshki leksikon. Lukich R. i M. Pechujlich (ur.). Beograd: Savremena administracija, 171-172.

KOVACHEVICH, I. (2009). "Modernizam i strukturalizam: Srpska etnologija/ antropologija u poslednjoj chetvrtini dvadesetog veka". Strukturalna 
antropologija danas: tematski zbornik u chast Kloda Levi-Strosa. Antonijevich, D. (ur.) Beograd: Srpski genealoshki centar, Odeljenje za etnologiju i antropologiju Filozofskog fakulteta, 8-30.

LUKICH, R. (1982). “Antropologija”. Socioloshki leksikon. Lukich R. i M. Pechujlich (ur.). Beograd: Savremena administracija, 11.

MARKOV, S. (1982). "Folklor". Socioloshki leksikon. Lukich, R. i M. Pechujlich (ur.). Beograd: Savremena administracija, 185.

MILICH, A. (1982a). "Kulturna antropologija”. Socioloshki leksikon. Lukich, R. i M. Pechujlich (ur.). Beograd: Savremena administracija. Beograd: Savremena administracija, 310-311.

MILICH, A. (1982b). "Socijalna antropologija". Socioloshki leksikon. Lukich, R. i M. Pechujlich (ur.). Beograd: Savremena administracija. Beograd: Savremena administracija, 603-604.

PRICA, I. (2005). "Autori, zastupnici i presuditelji: Hrvatska etnologija u paralelizmima postsocijalistichkog konteksta". Етнологија и антропологија: Cтање u перспективе. Зборник Етнографског института САНУ, бр. 21. Гавриловић, Љ (ур.). Београд: Етнографски институт Српске академије наука и уметности, 29-44.

STOJANOVICH, T. (1995). Balkanska civilizacija. Beograd: Centar za geopoetiku.

STOJANOVICH, T. (1997). Balkanski svetovi. Beograd: Equilibrium.

Dejan Krstikj

\title{
THE STATE AND THE POTENTIALS OF STUDYING AND APPLYING OF THE BALKAN TRADITIONAL CULTURE
}

\author{
Summary
}

This paper presents my own approach and opinion concerning the state and potentials of dealing with the Balkan traditional culture, i.e., its studies and applications. The paper shows a great confusion because of different terms and different perceptions of work fields of sciences that deal with or used to deal with traditional culture (folklore, ethnology, ethnography, ethno-linguistics, anthropology), although they study the same part of reality. The current tendency is the so called anthropologization, i.e., diverting from studying the traditional culture to studying modern phenomena (mostly traditions of the Western civilization). Studying of the traditional culture on the Balkans is in crisis, and, in general, the interest for it has decreased. Although the Balkan is a confluence, a meeting place of different civilizations (Western, Mediterranean, Oriental, Eastern European and the traces of Byzantine), because of historical circumstances and unique perennial ethnic and historical processes, it represents an original Balkan culture and civilization that absorbed many cultural elements of aforementioned civilizations.

When we discuss about the traditional culture on the Balkans, we think about this specific cultural type. There are no national traditional cultures (they are just national constructs), but there is a Balkan traditional culture that is immensely diverse and archaic. This paper presents the values of the Balkan culture that are the reasons for studying it and applying it in modern life in the future. The paper also suggests, given the present state, what needs to be done for this purpose. When dealing with it and applying it in the future, one should dispose of burdens of the past - the lack of appreciation of its value, 
artificial division into several fields of study, national-romantic perceptions of it, present methodological shortcomings, its confinement within national-state borders. In order to do this, scientific systems and attitude towards the use of traditional culture should be reorganized and essential multilateral activities at Balkan level should be carried out. 